\title{
埋め立て地盤に建つ大規模構造物の基礎設計と地盤変動計測

\author{
FOUNDATION DESIGN AND MEASUREMENT OF FLUCTUATION \\ IN LEVEL OF GROUND FOR LARGE-SIZED STRUCTURE \\ LOCATED AT RECLAIMED LAND
}

\author{
花島 晃*, 平野富之** \\ Akira HANAJIMA and Tomiyuki HIRANO
}

\begin{abstract}
In constructing a 256-m-high skyscraper on a reclaimed land, there are two problems awaiting solution; one is negative friction of piles due to consolidation settlement of alluvial clay layer under the reclaimed soil layer and settlement of diluvial clay layer locating deeper than the bearing stratum of the building. These were handled in conducting subsurface exploration, foundation design, study on construction methods and construction work at the site controlled by measurements.

Land settlement due to construction of a building should be estimated not only by evaluating increase in load and volume compressibility but also by considering 1) changes with time in ground-water table during excavation work and 2) load re-distribution effect due to rigidity of superstructure as a whole
\end{abstract}

\section{Key words: Land settlement, consolidation settlement, construction with measurement of settlement, skyscraper, foundation design, reclaimed land 地盤沈下、压密沈下、計測施工、超高層、基礎設計、埋め立て地盤}

\section{1. はじめに}

昭和40〜 46年に埋め立てたばかりの若い地盤である大阪南港に, 1995年 4 月，地上 52 階地下 3 階、高さ $256 m$ の超高首（写真 1 ）が竣工 した。この超高層の建設にあたり、埋め立て土の下の沖積粘土層の 圧密沈下による杭の負の摩擦力、大規模掘削による地盤のリバウン ド、支持層以深の洪積粘土首の圧密沈下などが問題点となり、これ らの解決が構造設計の課題となった。そこで、支持層に近い笔囲の 地盤の過圧密粘土の沈下を予測し、さらに埋め立て地盤に関する諸 課題の検討を行いながら設計を進めた。

今回、工事にあたって、建物と地盤の沈下計測を行ったので、予 測に対する検証と考察、施工での沈下対応について報告する。

\section{2. 地盤概要}

当敷地の 5 カ所のボーリング（深度 $\mathrm{G} \mathrm{L}-80 \sim 117 \mathrm{~m}$ ）を図 1 に示 す。上部埋め立て土層は層厚約 $20 \mathrm{~m}$ で磁〜砂〜シルト〜粘土が混在 し、N值は概ね10〜20程度である。上部冲積粘土首 $\mathrm{A}$ c は、埋め立 て荷重による 1 次圧密が末完了で、調查時点（1989.9）での残沈下 量は約 $5 \sim 30 \mathrm{~cm}$ と予測された。

下部の洪積粘土層は、上位よりDc 1 （Ma12）、Dc 2，Dc 3， Dc 4 とよばれ、ほぼ水平に成層分布している。最上位の洪積粘土 層D c 1 （Mai2）は、圧密降伏応力Pcが有効応力 $\sigma$ v'をやや上回 り、過圧密状態にある。Dc 2 は明らかに過圧密で、Pcー $\sigma$ 、’
$30 \mathrm{t} / \mathrm{m}$ である。下位の D c 3、Dc 4 は、Dc 2 ほど明暸に過圧密で ないが、多段階压密試験により、 Dc 3 は Pc- $\sigma_{\mathrm{v}}{ }^{\prime}>10 \mathrm{t} / \mathrm{m}^{2}$ 、

D c 4 は平均的にPc> $\sigma$ ' と判断できる。

洪積粘土と互層をなす洪積砂 D s $1 〜 4$ 、（砂砂層 Dg 1，Dg 3 ） は、いずれも N值が60を超えている。G $\mathrm{L}-47 \mathrm{~m} \sim 51 \mathrm{~m}$ 間のDs 1 を第 1 天満首、洪積粘土 D c 2 を挟むが、 G L - 63〜 76m間のD s 2 を第 2 天満層といい、一般に本地区の建物支持層となっている。

なお、今回の調查深度以下であるが、G L-130mからは、洪積 粘土層（Ma10）をはじめ、砂礫と粘土の互層の洪積層（大阪層群） が続いている。

\section{写真 1 建物全景}

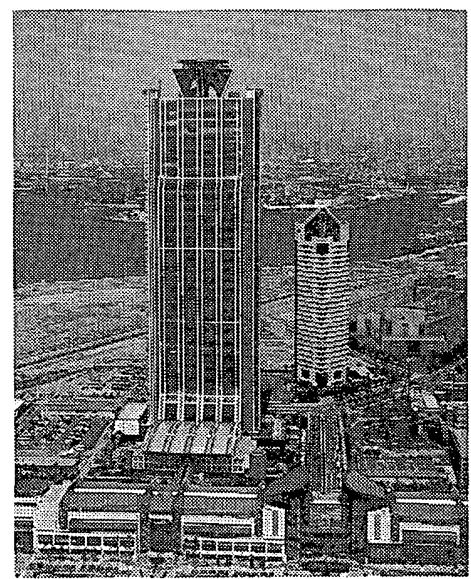

本論文の一部は，参考文献2)3）に発表している。

*日建設計大阪本社 データセンター室長

** 日建設計大阪本社 構造設計主管
General Manager, Data Center, Nikken Sekkei Ltd.

Senior Structural Engineer, Structural Engineering Department, Nikken Sekkei Ltd. 


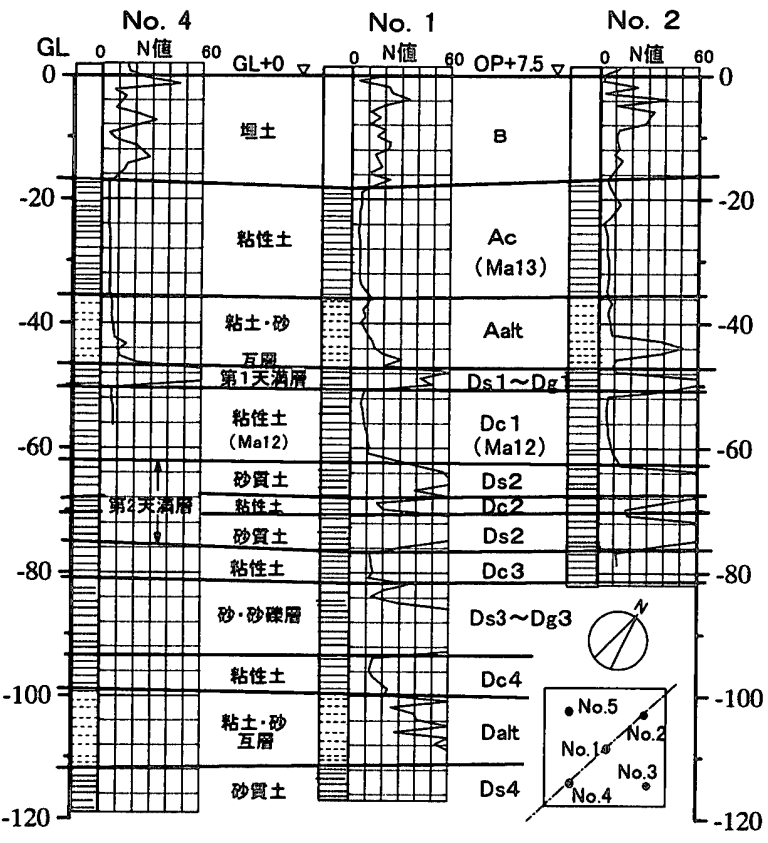

図 1 地盤概要図

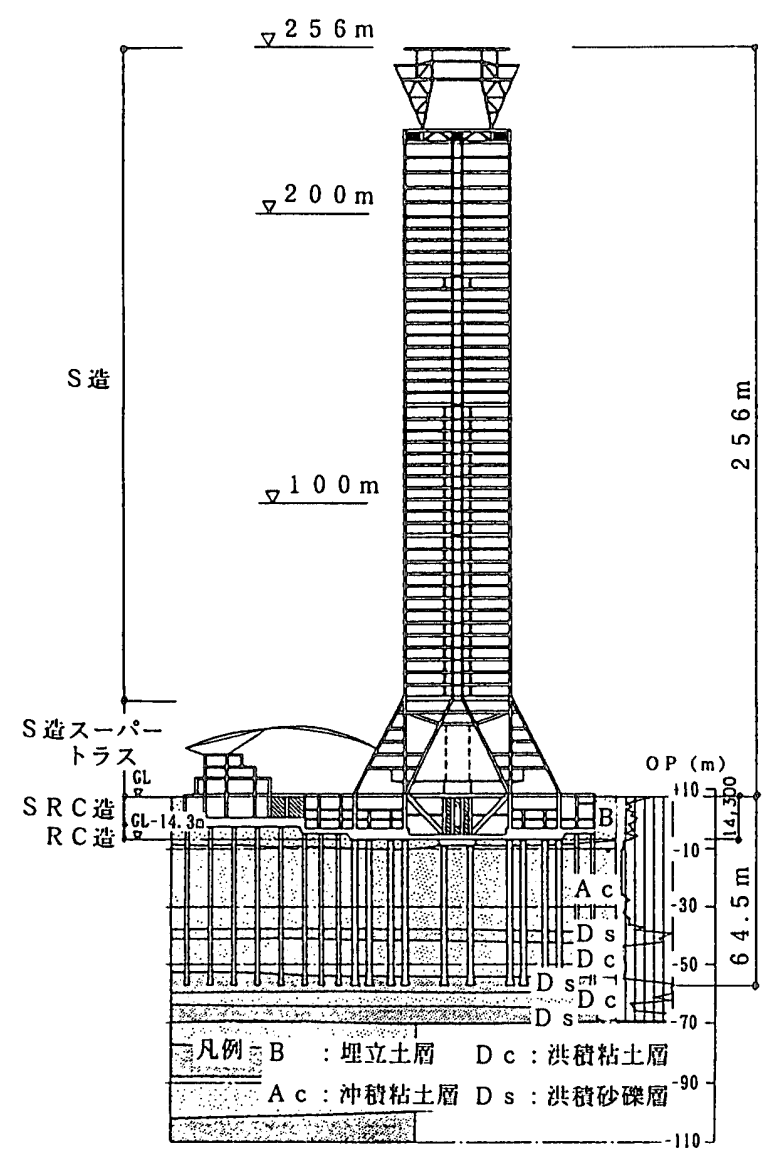

图 2 棈造概要図

\section{3．建物概要及び設計概要}

(1) 建物概要

建物は、鉄骨造地上55階地下 3 階、高さが $256 \mathrm{~m}$ 、延べ床面積が約 15 万 $\mathrm{m}^{2}$ にな。基準階の平面が約 $70 \mathrm{~m} \times 35 \mathrm{~m}$ で、短辺方向のアスペ
クト比が 7 のスレンダーなプロポーションである。

頂部の逆台形の展望台と、下部が 5 層吹き抜けの台形に拡がって いるのが特徴である。（写真 1 、図 2）

(2) 棈造設計概要

風、地震の転倒モーメントによる柱付加軸力を小さくするため、 7 階以下で、架構の外柱と内柱を外側に広げたスーパートラスとし た。さらに、地下階に格子状に厚さ $800 \mathrm{~mm} \sim 1200 \mathrm{~mm}$ 耐力壁を配置し、 地上部のスーパートラスとあわせ、立体的に超高層の基礎構造とし ての甽性と耐力を確保した。柱を外側に拡げた結果、支持地盤の高 層部負担面積は約 2 倍になった。

(3) 支持地盤

G L-47m以深の洪積砂層D s 1 （第 1 天満層）は、層厚も薄い。 直下の洪積粘土層 D c 1 （Ma12）の圧密降伏応力 P cが、有効応力 $\sigma$ 、'をやや上回る程度で、超高層の支持層として不十分であった。

一方、G L-63m以深のDs 2 (第 2 天満層) は、層厚約 $3 \mathrm{~m}$ 程の 過圧密洪積粘土層 D c 2 を挟むが、全体で $13 \mathrm{~m}$ 程度の堅固な地盤であ つた。そこで、D 2 （第 2 天满層）を杭の支持層として、杭先端位 置をGL-64mとした。杭は、G L-53mまで、杭周囲に摩擦力低減 材を塗布した内側リブ付き鋼管巻き場所打ちコンクリート拡底杭 ${ }^{1}$ とした。杭種は、高層部直下に対して、軸部径 $1800 \mathrm{~mm}$ で搪底径 3000 mmの拡底杭を104本（○印）、地下及び低層周辺部に対して、軸部径 $1100 \mathrm{~mm}$ 払底径 $1800 \mathrm{~mm}$ の拡底杭を 294 本（O印）とし、それぞれ建物平 面にほほ均等に配置した。（図 3 ）

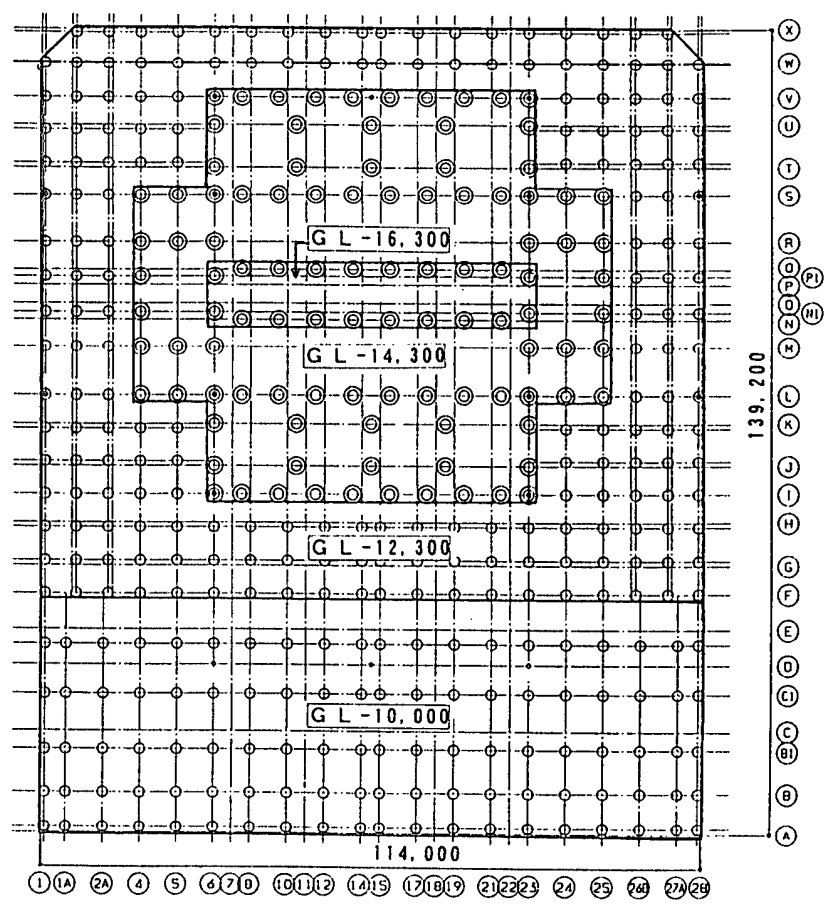

は礎板底レベル（=杭天端レベル）を示す

図 3 杭配置図

\section{（4）地中応力計算}

Bouss inesqの式で, 建物建設による増加地中応力を求めた。仮定と して、浮力を考慮した建物の有効重量が、負摩擦力低減杭により支 持地盤（G L-63mのレベル）に直接伝達するとした。また、高層部 の荷重は、台形に拡がった部分の杭群に囲まれた面積（図 3 に示す 
高層部礎板底 G L-14,300〜 16,300の篹囲）に、等分布荷重としてか かるとした。ただし、図 5 の建物荷重に示すように、軸力を外側に 分散させたことにより、中央の一部の荷重を 0 とした。

低層部の荷重についても同様に、杭群で囲まれた面積に等分布荷 重としてかかるとした。

掘削土荷重は、地表レベルで有効排土重量として除荷されるとし た。東西軸の地中応力の計算結果を表 1 に示す。

本敷地における洪積粘土の多段階圧密試験の圧密降伏応力の深度 テーターを、図 4 に示す。Dc 2 D D 4 の各洪積粘土層における建 設後の地中有効応力 $\sigma z^{\prime}$ は、いずれも圧密降伏応力 $\mathrm{P}$ C以下となっ た。

表 1 建物建設による地中増加空力

\begin{tabular}{|c|c|c|c|c|}
\hline \multirow{2}{*}{$\begin{array}{c}\text { 粘土層 } \\
\begin{array}{c}\text { 中央哚さ } \\
(\mathrm{m})\end{array}\end{array}$} & \multirow[t]{2}{*}{ 荷重状態 } & \multicolumn{3}{|c|}{ 応力（t/min) } \\
\hline & & $\begin{array}{l}\text { 地下外端 } \\
\text { (1)通 }\end{array}$ & 高㞗端部 & $\begin{array}{l}\text { 高屬中央 } \\
\text { (14) }\end{array}$ \\
\hline \multirow[t]{2}{*}{$\begin{array}{l}\text { Dc } 2 \\
\text { GL-70. } 5\end{array}$} & $\begin{array}{l}\text { 有効土被瓜 } \\
\text { 排土低減※ } \\
\text { 建物による堌加 } \\
\text { 有効応力 }\end{array}$ & $\begin{array}{r}57.0 \\
-6.8 \\
3.0 \\
53.2\end{array}$ & $\begin{array}{r}57.0 \\
-11.3 \\
23.9 \\
69.6\end{array}$ & $\begin{array}{r}57.0 \\
-12.7 \\
21.7 \\
66.0\end{array}$ \\
\hline & 圧密降伏応力 P c & \multicolumn{3}{|c|}{$85 \sim 107>$ 有効応力 $\sigma_{z}{ }^{\prime}$} \\
\hline \multirow[t]{2}{*}{$\begin{array}{l}\text { Dc } 3 \\
\text { GL-77. } 5\end{array}$} & $\begin{array}{l}\text { 有効土被圧 } \\
\text { 排土低減※ } \\
\text { 建物による増加 } \\
\text { 有効応力 }\end{array}$ & $\begin{array}{r}62.0 \\
-6.4 \\
3.9 \\
59.5\end{array}$ & $\begin{array}{r}62.0 \\
-10.1 \\
17.9 \\
69.8\end{array}$ & $\begin{array}{r}62.0 \\
-11.3 \\
14.2 \\
64.9\end{array}$ \\
\hline & \multicolumn{4}{|c|}{ 圧密降伏応力 $\mathrm{Pc} \quad 71 \sim 82.5>$ 有効忘力 $\sigma z$} \\
\hline \multirow[t]{2}{*}{$\begin{array}{l}\text { Dc } 4 \\
\text { GL-95. } 0\end{array}$} & $\begin{array}{l}\text { 有効土被玨 } \\
\text { 排土低減※ } \\
\text { 建物による增加 } \\
\text { 有効応力 }\end{array}$ & $\begin{array}{r}74.0 \\
-5.6 \\
4.9 \\
73.3 \\
\end{array}$ & $\begin{array}{l}74.0 \\
-8.2 \\
12.2 \\
78.0 \\
\cdots\end{array}$ & $\begin{array}{l}74.0 \\
-9.1 \\
12.3 \\
77.2\end{array}$ \\
\hline & \multicolumn{4}{|c|}{ 圧密降伏応力 $\mathrm{Pc} \quad 83.5$ >有效応力 $\sigma z^{\prime}$} \\
\hline
\end{tabular}

※図 5 に示す地表レベルの排土による地中応力減少

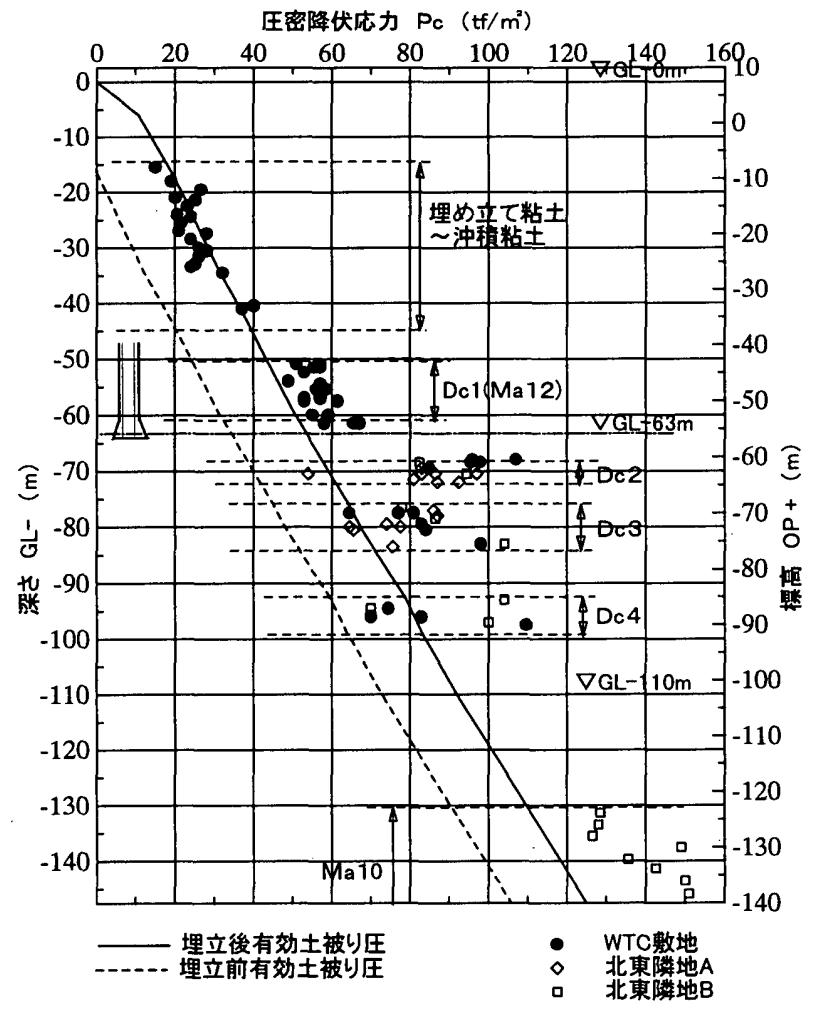

图 4 圧密降伏匛力度の深度データー

\section{4. 施工}

(1) 掘削工事

掘削規模は、面積 $15,000 \mathrm{~m}^{2}$, 最大深さ G L-16.5m, 全掘削土量が $225,000 \mathrm{~m}^{3}$ になる。掘削深さは、図 3 杭配置図において口で囲む数 値・礎板底レベルに示す。掘削工法は、高層部が敖地中央にあるた め、掘削と鉄骨建て方の両面から検討し、アイランド工法を採用し た。山留め止水壁はソイルセメント柱列とし、山留め変形防止と作 業スペース確保のため、1階の外周部の床スラブを、逆打ち工法で 先行打設した。

したがって、図 5 下の主要工程に示すように、高層部を先行掘削 し、高層地下躯体のコンクリート打設と同時に、周辺を掘削してい った。建物の沈下測定は、高層部基礎板コンクリート打設完了時か ら開始した。地下水対策は、7本のティープウエルを設置した。周辺 の一部は、地下躯体重量のみでは浮力の方が大きいので、地下躯体 が完成し建物重量が浮力（約10万 t f ）、を超えるまでディープウエル を稼動させた。設計水位は、G L-6. $0 \mathrm{~m}(\mathrm{O} P+1.5 \mathrm{~m})$ に設定した。 (2) 設計時の沈下予測

建設後の支持層下部洪積粘土層の地中応力は、圧密降伏応力度以 下であるが、過圧密比（OCR）が小さく、洪積粘土の過圧密領域で の沈下が予測された。そこで建物各部での 1 次圧密沈下を、有効地 中応力 $\sigma_{z}^{\prime}$ 之体積圧縮係数 $\mathrm{m} v$ 関係から求め、その沈下差を予測し た。

沈下計算は、影響の大きいと思われた建物支持層直下の洪積粘土、 すなわちDc $2 \sim 4$ の圧密沈下を対象とした。

計算上の仮定として、掘削の排土荷重と建物荷重が、地表と杭先 端位置 G L-63mレベルに同時に加わるとした。また竣工時までの等 価な圧密期間がおよそ200日と考え、1 次圧密沈下量を最終沈下量の 約 $80 \%$ とした。建物の用性は考慮していない。

G L - 130〜 148m間に、層厚の厚い洪積粘土層Ma10があるが、 Ma10は上位の洪積粘土首と異なり、堆積年代の古い洪積層（大阪層 群）に分類される固結度の極めて高い粘土層である。また、Ma10は、

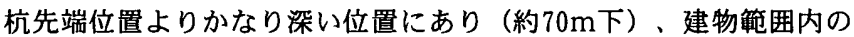
增加地中応力は平均化すると考えた。したがって、Ma10以深の洪積 粘土層の任密沈下は、躯体の不同沈下対策では考えないことにした。

沈下計算結果を表 2 の左に示す。

各部の沈下量は建物中央で $40 \mathrm{~mm}$ 、高層部の端部6通りで $76 \mathrm{~mm}$ とな り、高首端部の沈下が大きくなった。その端部と中央の沈下差は 36 $\mathrm{mm}$ 、周辺の地下外端との沈下差は、高層端部の沈下量そのままの76 mmになった。

沈下差の対策として、地下部のコンクリート打設施工時期をずら すこと、施エレベルをあらかじめ調整するなどを、設計時における 施工計画とした。

(3) 施工時の沈下予測再計算

設計時の沈下計算方法は、浮力および排土も含めた全荷重が同時 に加わる仮定である。一方、実際の工事では、それぞれの荷重が時 系列で変動する。そこで実際の施工順序に即した沈下を予測するこ とにした。

ただし、掘削に関しては、計算を簡単にするために、1992年 3 月、 図 5 の右下に示す排土が、周辺も含め全て同時に完了したと考えた。 そして、掘削完了時点からの沈下量を計算した。 
具体的には、図 5 に示す建物荷重W $1 \sim 3$ を、G L-63mレベルに 段階的（3ヶ月毎）に加わえ、沈下量を累加した。荷重負担の範囲 と深度レベルは、設計時の沈下計算で想定したものと同じである。 再計算結果を、表 2 の右に併せて示す。

再計算では、竣工時の沈下量が最終沈下量計算の $95 \%$ になった。 低虽外周で $0 \sim 15 \mathrm{~mm} 、 \mathrm{~F}$ 通りで21 mm、高層端部 6 通りで $118 \mathrm{~mm} 、$ 高 斀中央 14 通りで $82 \mathrm{~mm}$ で、設計時予測の高層端部 $76 \mathrm{~mm} 、$ 中央 $40 \mathrm{~mm}$ の值 の約1. 5〜2 倍になった。

この理由として、再計算では、建物荷重に工事中の水位低下を考 虑したこと、および、竣工時の圧密沈下が、最終沈下量の約 $95 \% に$ なったことなどによる。

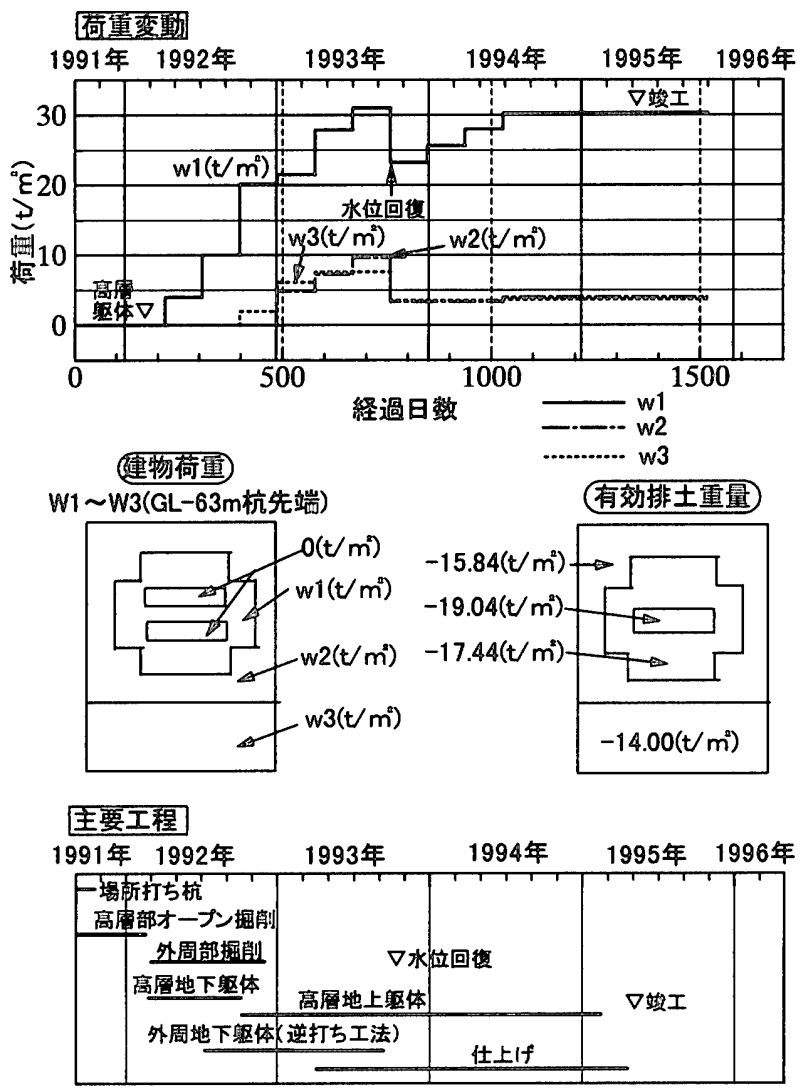

図 5 各施工段階における建物荷重変動と主要工程

表 2 予測沈下差計算

単位 : $\mathrm{mm}$

\begin{tabular}{|c|c|c|c|c|c|c|}
\hline \multirow{2}{*}{ 層別訧下 } & \multicolumn{3}{|c|}{ 設計時 (U $80 \fallingdotseq 200$ 日) } & \multicolumn{3}{|c|}{ 施工時再計算 (竣工時) } \\
\hline & (1)通 & (6)通 & (14)通 & (1)通 & (6)通 & (14)通 \\
\hline $\begin{array}{l}\mathrm{Dc} 2 \sim \mathrm{Dc} 4 \\
(\mathrm{GL}-63 \sim 110 \mathrm{~m})\end{array}$ & 0 & 76 & 40 & 0 & 118 & 82 \\
\hline GL-110m以深 & \multicolumn{3}{|c|}{ 建物内で炕下差はない } & \multicolumn{3}{|c|}{ 同 左 } \\
\hline 建物内沈下差 & 76 & & & 118 & & \\
\hline
\end{tabular}

以上、再計算では 100 m以上の沈下差が生じるとなった。しかし、 実際は躯体の則性による沈下差の低減があると考え、実施工の対応 は、計算結果の $50 \%$ とって、高層部の 1 階レベルを、設計值より $+50 \mathrm{~mm}$ 上げて施工することにした。

設計時は、沈下による建物間の強制変位によって、大きな部材応
カが生じないように、地下の高層部と低層部の取り合いコンクリー トの打設を、竣工時近くで行う計画をしていた。しかし、工程上、 難しくなったため、一体で施工することに変更した。その結果、沈 下差による強制変形分の応力が、構造躯体各部に生じることになっ たので、それを考慮して、部材断面の鉄筋補強を行った。

\section{5. 站盤及び建物沈下計測}

(1) 計測方法

洪積層の沈下性状を確認するため、建物と周辺地盤のレベル測定 および層別沈下計によって、地盤層別の圧縮量を計測した。

建物の沈下計測の方法は、旉地より $1 \mathrm{~km}$ 東の南港内の港湾局の水 準点から、各ポイントの絶対高さレベルの測定を行い、その累積値 を耽下量とした。測定は地表面については1991年 9 月、建物につい ては1992年 1 月から始めた。測定は 2 ヶ月に一度行い、竣工後 5 年 間、年に一度行う。

測定ポイント位置を図 6 に示す。

層別の圧縮量を計測するため、掘削工事開始前に、層別现下計を 高層中央（B15の位置）と、敷地南東端（G５の位置）に設置した。 高層部の層別沈下計は、掘削途中、計器不良になったため、新た にG L-63mとG L-110mの地中に定着したアンカーロット゚と、基礎 底面の相対変位を測定する沈下計（連続沈下計）を設けた。それに より定着間 G L-63〜110mの地盤圧縮量をまとめて計測することに した。

B 1〜B 22は建物本体の測定ポイント、B $1 \sim$ B 7 は掘削前に施 エした先行 1 階スラブ上のポイント、B 8 ～B 22は掘削後に礎板を 打設してから設けたポイントを示す。G 5 を除く G 1 〜 G 9 は地表 面の測定ポイントを示す。G 5 は、 G L-110mにアンカーした層別 沈下計N 3 のロッド天端測定位置を示す。N 1，N 2 は、それぞれ G L-110m, G L-63mに定着アンカーした沈下計の位置を示す。

\section{(2) 計測結果}

図 6 の右及び下のグラフは、1996年 3 月までの高層部中心断面に おける建物沈下形状を 1 年毎に表したものである。

図 7 は各測定ポイントの沈下を示したものである。沈下量のグラ フの起点は、ポイントをセットした時点でレベルを測定し、その值 をゼロとしたものである。

計測結果によれば建物側の沈下は、1994年の11月以降減少してい る。建物鱼量としては、1994年 4 月にほぼ全重量が載荷されており、 大きな圧密のタイムラグが約半年間あった。

地下 3 階コンクリート床打設（1992年 3 月）～建物竣工（1995年 3 月）までの約 3 年間の全沈下量は、高層中央（B 15）で $106 \mathrm{~mm}$ ，高 層端部（B 13）で最大 $107 \mathrm{~mm}$ ，外周部（B 1) で最大 $110 \mathrm{~mm}$ となった。 途中経過では、沈下が中央が先行して大きかった。上部構造がほ ぼ完成した後半は、端部の沈下量がやや大きくなり、最終的には高 阄部の範囲でほぼ均等沈下となった。

建物の影響の少ないと思われる敷地南東端 G 5 （G L-110m）の 沈下量が79m片あったことから、竣工までの建物沈下の過半は、G L-110m以深の沈下である。

D c 2 4 の洪積粘土の沈下計算は、建物荷重が高層部範囲に均等 にかかるとしたが、中央の一部の荷重を 0 としたため、端部の沈下 が大きかった。

しかし、実際の計測結果は、ほぼ均等になった。この理由は、外 
へ拡げた部分を除いて、高層部の上部構造躯体が、先行して施工さ れたこと、地下 3 階分厚さ $1000 \mathrm{~mm}$ の耐力壁と、地上 7 階までのスー パートラスが一体となり、基礎としての剛性が非常に高かったこと などにより、沈下を平均化したと考えられる。

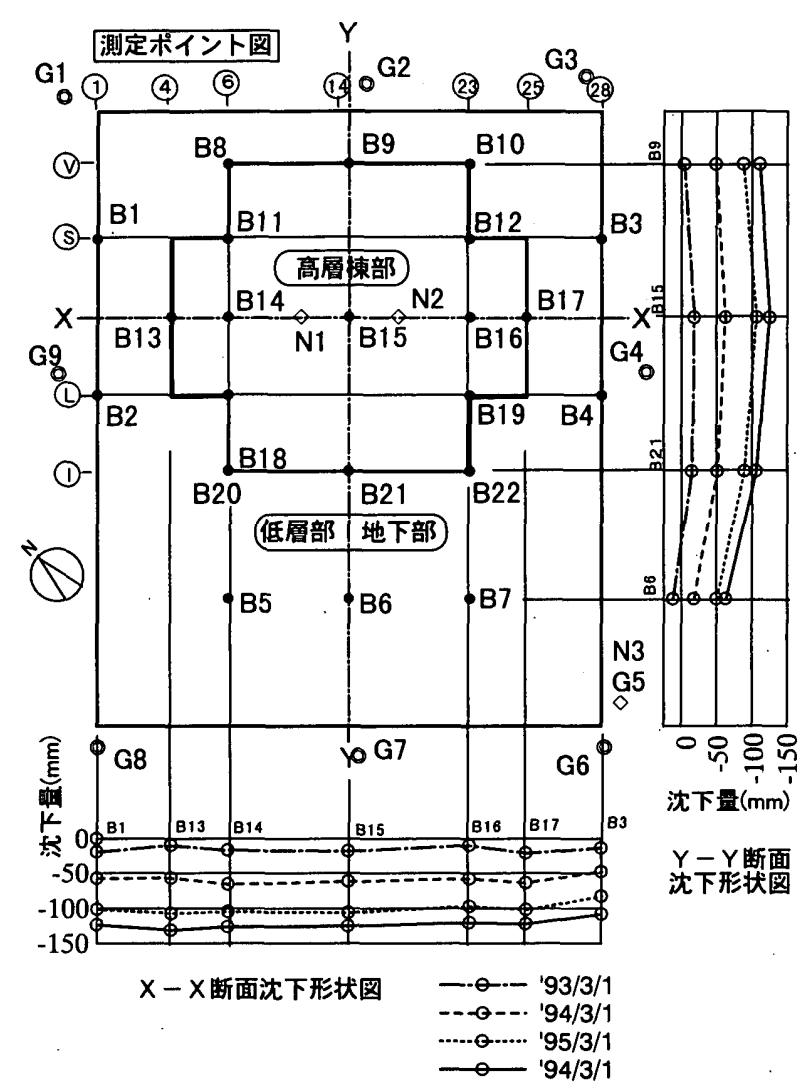

图 6 測定ポイント位置および断面沈下形状

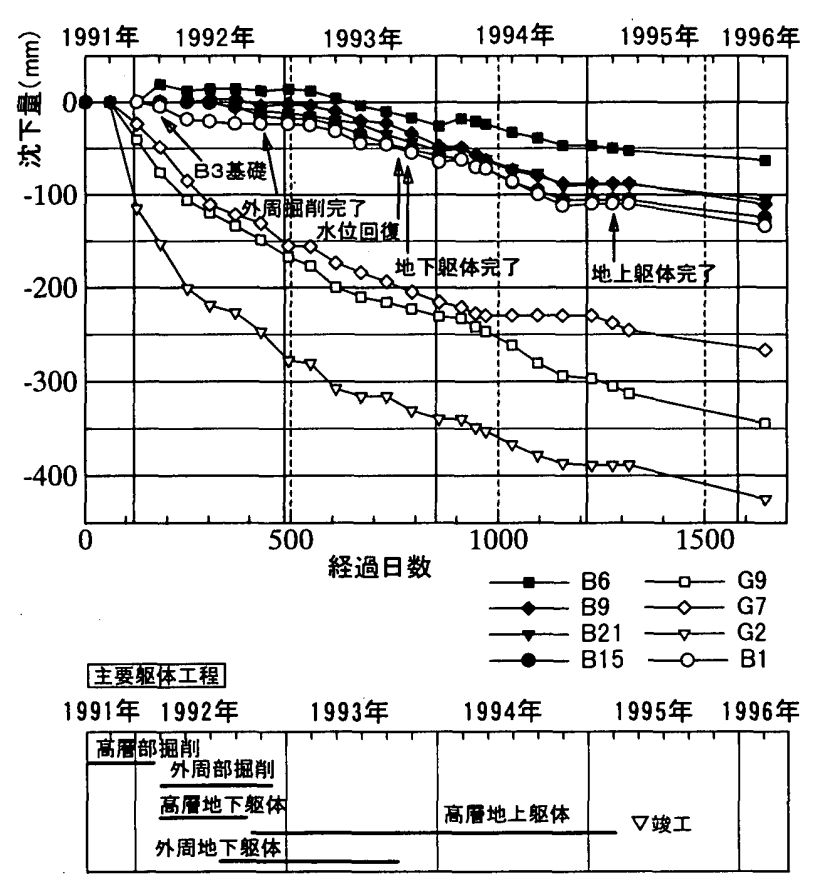

図 7 代表測定ポイントの沈下量
（3）高層部直下および周辺の地盤の圧密沈下

図 8 に、高層部直下の地盤沈下性状を示す。G L-110mおよびG L-63m以深の沈下として、層別沈下計 N 1 、 N 2 のロッド天端の沈 下を同図に示す。

建物周辺の地盤の沈下データーとして、敷地南東端 N 3 の建設開 始から、1996年 4 月までの層別の沈下計測を、図 9 に示す。

周辺地盤の地表の沈下として、G 6 の測定も図 9 に示すが、地表 の沈下結果は、A c からD c 4 までの層別の沈下合計と G L-110m 以深の沈下 (G 5 ) の和にほほ等しい。

表 3 に、高層部直下の層別沈下計 N 1、N 2 、周辺地盤のN 3 の 測定結果も含めて、竣工時と竣工後 1 年の各地中レベルでの沈下を 数値で示す。高層部の建物沈下は G L - 63m以深の沈下よりやや大き い。

高層部直下の G L-110m以深の沈下速度は、大きく見て年間平均 約 $10 \mathrm{~mm}$ となる。周辺地盤のG L-110m以深の沈下として、G 5 の計 測結果を図 8 にも示すが、高酋部直下よりかなり大きい。表 3 に数 值で示すが、高層部直下の沈下が、竣工時、43mmに対し周辺が $80 \mathrm{~mm}$ となり $37 \mathrm{~mm}$ もきい。この理由として、実際には周辺の掘削が後施 エになったため、その掘削による荷重除荷で、中央の沈下が少なか ったと考えられる。なお、竣工後 1 年間の沈下量でも高層部 $9 \mathrm{~mm}$ 対し、周辺 $12 \mathrm{~mm}$ でやや周辺が大きい。これは高層部および周辺 $\mathrm{F}$ 〜 X通り間の掘削土の重量が約27万 $\mathrm{t} f$ に対し、建物重量が約 22 万 $\mathrm{tf}$ で、荷重バランスとして、建物がやや軽いからと思われる。

高層中央の沈下計 N 1, N 2 の差、すなわち G L -63〜110m間の 圧縮量を図 8 および表 3 に示しているが、建物中央の掘削完了〜竣 工時、杭支持層以下の G L-63m〜 - $110 \mathrm{~m}$ までの圧縮量は $52 \mathrm{~mm}$ で、 $\mathrm{G}$

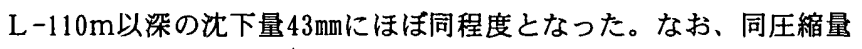
は、竣工後 1 年で $9 \mathrm{~mm}$ 増加した。

竣工時までの周辺地盤のD c 2 からD c 4 の層別の圧縮量の合計、 すなわち、G L-63〜110m間の圧縮量を表 3 に数値で示すが、 $17 \mathrm{~mm}$ と高層直下 $52 \mathrm{~mm}$ と比べかなり小さい。高層部直下の洪積粘土が、建 物荷重の影響を直接受けて、沈下が大きくなったといえる。

この周辺との沈下差 $35 \mathrm{~mm}$ は、たまたま $\mathrm{G} \mathrm{L}-110 \mathrm{~m}$ 以深の高層部と

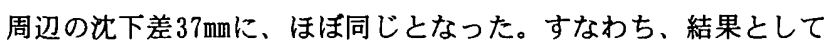
G L-63m以深の沈下は、竣工時において、高首部中央も周辺敷地も 同じとなった。

B 5〜 7 ポイントの低層部の建物沈下測定結果は、G L-110mの 沈下の $70 \%$ と小さい。ただし、図 7 でわかるように、B $5 \sim 7$ ポイ ントがリバウンドによって初期に15～19mm浮き上がっている。これ を低層部の建物沈下に加えると周辺地盤の G L $-110 \mathrm{~m}$ 以深の沈下 $\mathrm{G}$ 5 の推移とよく対応する。

工事中、低層部の建物は、1階床打設後、逆打ち工法による地下 掘削のため、G L-63〜110m間の地盤がリバウンドし、建物が浮き 上がったが、G L-63〜110m間の沈下はほとんどなく、G L-110m 以深の沈下が、建物沈下となっていると思われる。

竣工後 1 年間の低層部B 6 の建物側沈下量は $13 \mathrm{~mm}$ で、周辺 $\mathrm{N} 3$ の 層別沈下の計測によるG L-63m以深の沈下量 $13 \mathrm{~mm} に 、$ 同じとなった。 (表 3) 


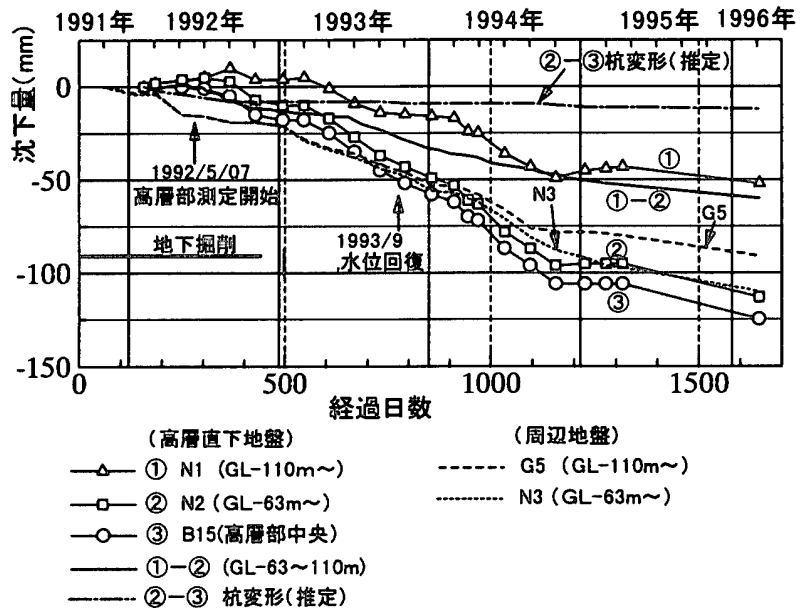

图 8 洪積層沈下と建物沈下の関係

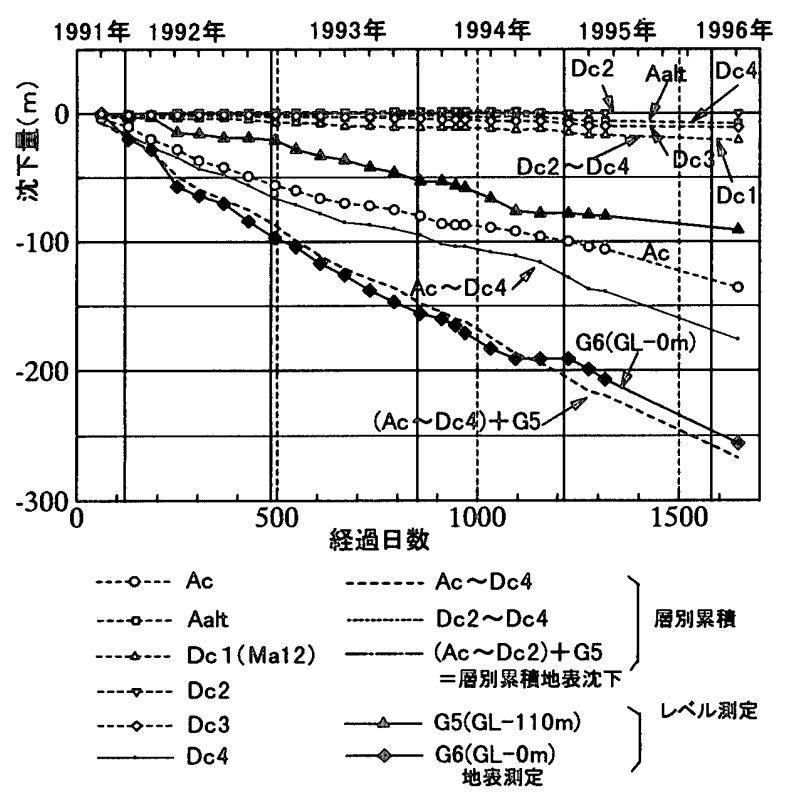

图 9 周辺地盤の圧密沈下

\begin{tabular}{|c|c|c|c|c|}
\hline \multirow{2}{*}{$\begin{array}{l}\text { 場所 } \\
\text { 圧縮量or沈下星 }\end{array}$} & \multicolumn{2}{|c|}{ 高層直下（N1, N2） } & \multicolumn{2}{|c|}{ 周辺地盤 (N3) } \\
\hline & 1995年3月 & 1996年3月 & 1995年3月 & 1996年3月 \\
\hline $\mathrm{GL}-63 \sim 110 \mathrm{~m}$ & 52 & 61 & 17 & 19 \\
\hline GL-110 & 43 & 52 & 80 & 91 \\
\hline GL-63〜 & 95 & 113 & 97 & 110 \\
\hline 建物沈下 & $106(B \mid 5)$ & 125 (BI5) & $\begin{array}{r}50(\mathrm{~B} 6) \\
※ 69(\mathrm{~B} 6)\end{array}$ & $\begin{array}{r}63(\mathrm{~B} 6) \\
※ 82(\mathrm{~B} 6)\end{array}$ \\
\hline
\end{tabular}

6. まとめ

建物の沈下と地盤の支持層以下の沈下計測結果は、よく一致して いる。

洪積層が深く堆積している埋め立て地では、建物荷重と莫大な埋 め立て土荷重と合わせると、洪積粘土が過圧密領域でかなり圧密沈
下する。

建物荷重が、支持層直下の洪積粘土の沈下に大きく影響するのは 当然であるが、地表の広範囲の大規模掘削が、かなり深くまで地中 応力を減少させ、洪積粘土全体の圧密沈下を小さくしている。

今回、建物荷重が異なる高層部と低層部の沈下差は、荷重の違い による支持層直下 G L - 63〜 - 110m間の洪積粘土の圧密沈下量の差 だけでなく、施工順序、特に高層部を先行した掘削時期の違いによ るリバウンド量の差などが大きい。

大規模掘削により、G L-110m以深の沈下速度が、工事中、小さ くなった。その結果、特に敖地中央の高層部の建物沈下を減らした。 また、予測計算で大きかった高層部と周辺低層部との沈下差を小さ くした。

G L - 63〜 -110m間の洪積粘土の圧密沈下は予測計算より小さかっ た。また高層部䉪囲でほぼ沈下が均等となった。これは過圧密粘土 のmv值の評価、実際の有効応力の違い、建物の荷重伝達の変動、 杭周囲の地盤も含めた上部構造の剛性の寄与などがあったと考えら れる。

このような埋め立て若齢地盤に建つ大規模構造物の基礎設計は、 特に応力増加の影響が大きい支持層直下の地盤特性、地表の排土に よる地中応力の減少によるリバウンド、建物に働く浮力と施工順序 の検討、さらにそれら沈下差となって表れる変動要素を吸収してし まう上部構造の剛性の確保が重要である。

\section{鲋辞}

基礎設計にあたり、京都大学名誉教授赤井浩一、京都大学教授嘉 門雅史、関西大学教授山屃邦男の諸先生方ならびに大阪市港湾局木 山正明氏にご指導いただきました。また、本計画および地盤計測に あたり、(侏大阪ワールドトレードセンタービルディングの関係者の 方々のご理解と、施工関係者の方々および（株）日建設計中瀬土質 研究所の角南進氏のご協力をいただきましたことを記しまして、こ こに感謝の意を表します。

\section{考文献}

1) 花島晃・梅原弘記 - 加藤克巳 : 大阪ワールトトトレードセンター（大阪咲州） 基礎杭の設計之施工, 基礎工, pp56-67，1991.12

2) 花島晃、平野富之、陶器浩一：大阪ワールドトレードセンタービ ルの基 碳設計と地盤変動計測（その 1 基礎設計と地盤応力）, 日本建築学会学 術講演梗概集（北海道）、pp957〜 pp958, 1995.8

3)平野富之、花島晃、陶器浩一 : 大阪ワールドトレードセンタービルの基 碳設計と地盤変動計測（その2 地盤变位計測）, 日本建築学会学術講演 梗概集（北海道）,pp959〜 pp960,1995.8

（1996年 9 月 9 日原稿受理，1997年 1 月 30 日操用決定） 